\title{
PERILAKU GAMBLER FALLACYDALAM MENGELOLA KEUANGAN PRIBADI (SUATU KAJIAN PUSTAKA)
}

\author{
Peter Garlans Sina*
}

\begin{abstract}
The aim of this research is to provide evidence of gambler fallacy behavior in a personal financial management which could impede the achievement of financial freedom such as managing the expenditure and saving inaccurately. By developing a comprehensive understanding that the value of probability is equal for both the expected and not expected events and not creating a financial decision in a hurry are the ways in reducing the problem.
\end{abstract}

Key word : gambler fallacy, personal finance, spending, saving

\section{PENDAHULAN}

Mengelola uang merupakan seni dan ilmu karena membutuhkan pemahaman serta keberanian untuk mengaplikasikan. Tidak hanya itu saja, dikaitkan dengan kondisi saat ini yang penuh ketidakpastian, relevansi manajemen keuangan pribadi sangat penting untuk diperhatikan. Dengan kata lain yaitu pengelolaan keuangan pribadi sebaiknya jangan diabaikan dan perlu meningkatkan pengetahuan sehingga apabila terjadi perubahan yang doluar dugaan maka orang atau pun keluarga dapat mengantisipasi atau mungkin dapat memperkecil peluang mengalami kesulitan keuangan.

\footnotetext{
Alumni Magister Manajemen UKSWSalatiga, JL Galah Mada No 58 Fontein Kupang-NTT, petersina83@gmail.com, 082115197954
}

Seperti yang diungkapkan
oleh Wibawa (2003: 32) dalam
Warsono (2010) bahwa selama
hidupnya, setiap manusia pada
umumnya mempunyai tujuan yang
ingin dicapai. Tujuan hidup ini dapat
saja berbeda antar manusia, tetapi
pada umumnya mereka ingin
mencapai hidup yang bahagia baik
di dunia maupun di akhirat. Manusia
akan hidup bahagia jika sukses
mencapai apa yang diimpikannya.
Kesuksesan hidup manusia di dunia
ini dapat diindikasikan dengan
berbagai macam ukuran, seperti
harta yang berhasil dikumpulkan,
jenjang karier atau jabatan yang
dicapai, tingkat pendidikan yang
dilalui, penyiapan generasi
penerusnya, dan kontribusinya
terhadap kehidupan.
Masih dari sumber yang
sama, dalam bidang keuangan,
manusia atau orang dikatakan


sukses dan mencapai kebahagiaan jika sudah mencapai kemerdekaan keuangan (financial freedom), dalam arti uang sudah tidak lagi dijadikan sebagai tujuan kehidupan. Semua aktivitas dan keputusan kehidupan sudah tidak lagi sematamata ditujukan untuk uang, tetapi uang dipandang sebagai sarana mencapai tujuan yang lebih hakiki. Uang tidak lagi mengendalikan kehidupan seseorang, tetapi oranglah yang mengendalikan uang. Masih banyak hal-hal lain yang lebih menentukan kehidupan, seperti kesehatan, anak, keluarga, sahabat, amal ibadah, dan lain-lain.

Selanjutnya, berdasarkan hasil penelitian Sina (2011) bahwa gambler fallacy merupakan salah satu bias yang menyebabkan orang atau pun rumah tangga mengalami kekeliruan dalam mengelola keuangan keuangan. Lebih spesifiknya yakni individu atau pun rumah tangga mengalami kesalahan dalam membuat keputusan keuangan karena menggunakan cara berpikir gambler fallacy. Efek lanjutannya yaitu individu atau pun rumah tangga menurunkan peluang untuk membangun aset dan dapat saja mengalami peningkatan utang yang berlebihan.

Fenomena gambler fallacy yang dapat diamati di Indonesia adalah tingkat keyakinan konsumen akan kondisi ekonomi Indonesia semakin membaik. Riset The Nielsen Company Indonesia per kuartal III2011 menunjukkan, 86\% konsumen Indonesia merasa nyaman dengan kondisi keuangan mereka. Angka ini naik tujuh poin dibandingkan kuartal II-2011. Ini menjadikan Indonesia negara teratas paling optimistis dengan kondisi finansialnya. Selanjutnya ialah Brasil 78\% dan India $77 \%$.

Riset ini melibatkan 28.000 pengguna internet di 56 negara. Imbasnya, indeks kepercayaan konsumen (CCI) Indonesia mencapai 114 , naik dua poin dari kuartal sebelumnya. Catherine Eddy, Direktur Pengelola Nielsen Indonesia berujar, hal ini menyebabkan orang tak ragu menabung atau berbelanja. Di samping itu, ia pun menilai keyakinan konsumen bisa dilihat dari bertambahnya jumlah masyarakat kelas menengah serta meningkatnya pendapatan. Alhasil, kualitas dan kuantitas barang yang dibeli juga meningkat (Kontan, 10 November 2011).

\section{Masalah dan Tujuan}

Berpijak pada ulasan sebelumnya, tampak bahwa gambler fallacy merupakan salah satu penentu individu atau pun rumah tangga mengalami kekeliruan mengelola keuangan, dan hal ini mengakibatkan berbagai efek negatif yang membuat peluang mewujudkan kebebasan keuangan menjadi terhambat. Bukan hanya itu saja, efek-efek negatif tersebut juga berpeluang mengakibat efek berantai yang menyebabkan individu atau pun rumah tangga meningkatkan peluang mengalami 
kesulitan keuangan yang tidak berkesudahan. Oleh karena itu, berbagai efek negatif itulah yang menjadi alasan fundamental dibuatnya penelitian ini. Untuk itu, tujuan yang hendak dicapai yaitu memberikan bukti terkait perilaku gambler fallacy dalam pengelolaan keuangan pribadi (personal finance) sehingga dapat direduksi ketika membuat keputusan keuangan di waktu yang akan datang.

\section{PEMBAHASAN}

\section{Manajemen Keuangan Pribadi}

Pada prinsipnya keputusan keuangan yang diambil bermaksud mengoptimalkan kemakmuran atau kesejahteraan individu maka pengambilan keputusan merupakan suatu hal yang kompleks mengingat perlu mempertimbangkan situasi dan informasi secara cermat dengan cara melakukan analisa yang kritis, mendalam dan komprehensif. Menurut Gitman dalam Krishna, Rofaida, dan Sari (2010) bahwa secara umum manajemen keuangan didefinisikan sebagai seni dan ilmu mengelola uang. Lebih lanjut manajemen keuangan merupakan proses perencanaan, analisa dan pengendalian kegiatan keuangan. Salah satu bentuk aplikasi dari manajemen keuangan adalah yang disebut manajemen keuangan pribadi (personal finance) yaitu proses perencanaan dan pengendalian keuangan dari unit individu atau keluarga. Personal Finance meliputi : (1) Money Management, (2) Spending and
Credit, dan (3) Saving and Investing.

Sedangkan menurut Shefrin (2007) bahwa pengeluaran dan penghasilan rumah tangga seolaholah senantiasa kejar mengejar untuk saling memenangkan perlombaan, dan dapat diduga seringkali yang menajdi pemenangnya adalah pengeluaran sehingga benar adanya jika ada pepatah yang mengatakan bahwa perilaku rumah tangga terhadap uang lebih penting dibandingkan seberapa banyak uang yang dimiliki. Namun, banyak rumah tangga yang belum menyadari pentingnya pengelolaan keuangan, dengan alasan jumlah penghasilan kecil sehingga terlalu kecil untuk dikelola, sementara yang berpenghasilan besar juga merasa punya banyak uang sehingga tak memerlukan pengelolaan keuangan lagi. Pada prinsipnya terdapat dua jenis perilaku individu terhadap uang, yakni penabung (saver) atau pembelanja (spender). Oleh karena itu, dalam penelitian ini akan menggunakan definisi menurut Shefrin (2007) menimbang lebih spesifik dan lebih diarhkan pada keuangan berbasis perilaku.

\section{Gambler Fallacy}

Gambler fallacy menurut Hirschey dan Nofsinger (2008) adalah seseorang cenderung berkeyakinan akan terjadi koreksi dengan sendirinya dalam suatu perjudian yang adil (negative recency effect). Sumber lain, 
Kahneman dan Fredirick (2001) mengungkapkan bahwa definisi bias prediksi yaitu individu berharap suatu rangkaian peristiwa yang dihasilkan dari proses random akan merepresentasikan suatu karakteristik tertentu, bahkan ketika rangkaian terjadi dalam jangka pendek, sehingga dapat dikatakan bahwa bentuk ini memfokuskan pada bias pada saat memprediksi peristiwa random.

Lebih lanjut, bias prediksi sering juga disebut local representativeness bias, yang mana akan termanifestasi dalam bentuk gambler fallacy, sedangkan Hirschey dan Nofsinger (2008: 218) menambahkan hot hand fallacy. Adapun definisi dari gambler fallacy yaitu seseorang cenderung berkeyakinan akan terjadi koreksi dengan sendirinya dalam suatu perjudian yang adil (negative recency effect), sedangkan hot hand fallacy adalah keyakinan bahwa rangkaian peristiwa pada masa lalu akan terus berlanjut dimasa yang akan datang (positive recency effect).

\section{Segi Pengeluaran dan Menabung}

Perencanaan pengeluaran merupakan keharusahan ditengah banyaknya persoalan ekonomi yang mengimpit dan menjepit setiap individu dan keluarga. Walaupun tidak ada aturan baku, pengeluaran untuk kebutuhan hidup sebaiknya maksimum 70\% dari penghasilan. Untuk itu perlu memperhatikan tiga hal yakni menabung, gaya hidup dan menunda kesenangan. Menabung berkaitan dengan menabung dulu baru sisanya digunakan untuk belanja. Jangan sebaliknya, membayar dulu baru sisanya ditabung. Gaya hidup berkaitan dengan di era indormasi sekarang ini, menaikkan standar gaya hidup sudah menjadi keharusan demi faktor gaya dan gengsi. Walaupun tidak mampu. Bahkan, banyak pihak yang menggunakan kartu kredit untuk meningkatkan gaya hidup.

Sebaliknya banyak pula pihak yang sulit menurunkan standar gaya hidup karena selain sudah merasa nyaman dengan standar gaya hidupnya yang tinggi, pada umumnya tidak ingin dikatan sedang mengalami kesulitan keuangan. Tujuan dari penetapan standar gaya hidup adalah agar tidak mengalami defisit atau besar pasak daripada tiang. Oleh karena itu, alangkah baiknya jika persentase kenaikan untuk gaya hidup lebih kecil dibandingkan dengan persentase kenaikan gaji. Tujuannya adalah agar tabungan reguler yang diperoleh lebih besar. Menunda kesenagan dimaksudkan yakni menunda kesenangan bukan berarti tidak menikmati hidup layak, bukan pula pelit.

Menunda kesenangan lebih menekankan pada pola hidup sederhana dan bijaksana, lebih mendahulukan kebutuhan dibandingkan keinginan. Lebih lanjut, dengan mempraktikkan pola 
hidup menunda kesenagan, akan lebih mampu melakukan pengendalian terhadap pola pembelanjaan (Karvof, 2010 : 121126). Serupa, Senduk (2004: 12-20) mengungkapkan bahwa atur pengeluaran anda. Caranya usahakan kalau perlu sedikit lebih keras pada diri untuk tidak mengalami defisit karena defisit adalah sumber semua masalah besar yang mungkin muncul di masa mendatang. Prioritaskan pembayaran cicilan utang, lalu premi asuransi, kemudian biaya hidup. Pelajari cara mengeluarkan uang secara bijak untuk setiap pos pengeluaran. Hal itu dimaksudkan supaya individu atau pun rumah tangga memiliki dana yang mencukupi untuk membiayai pengeluaran saat ini dan di masa mendatang.

Tidak jauh berbeda, Sina (2011) mengungkapkan bahwa memperoleh kebahagiaan dalam hidup merupakan tujuan yang ingin diwujudkan oleh siapa saja, dan hal ini menuntut banyak upaya dan kesabaran. Terkait manajemen keuangan maka tujuan yang dingin diwujudkan adalah mencapai kebebasan keuangan, dan salah satu syarat yang dapat dilakukan adalah dengan menabung. Hanya saja, seringkali salah dalam mengelola pendapatan. Maksudnya adalah keliru dalam mengalokasikan uang yang diperoleh setelah bekerja, dan hal ini berimplikasi pada kebiasaan menabung yang rendah. Lebih lanjut, tanpa adanya upaya membangun kebiasaan menabung maka seseorang secara eksplisit tidak peduli dengan masa depan keuangan. tanpa kepedulian akan masa depan keuangannya maka hanya akan meningkatkan peluang tidak tercukupi uang ketika pensiun karena lebih suka membelanjakan uangnya saat ini dan tidak menyisakan untuk disimpan atau di tabung.

Dikaitkan dengan gambler fallacy, Dohmena, Falkb, Huffmanc, Markleind, dan Sundee (2009) menyatakan bahwa menggunakan cara berpikir gambler fallacy mengindikasikan kemampuan memproses informasi yang lebih kurang tinggi sehingga kurang mampu membuat penilaian informasi yang rasional terhadap setiap keputusan keuangan yang dibuat. Atau dengan kata lain seseorang yang memiliki daya nalar kurang tinggi akan kurang mampu mengatur pikiran dengan cara yang tepat untuk menjadi jelas dan mudah dimengerti.

Lebih lanjut, dengan kemampuan mengolah informasi yang kurang tinggi dapat mengakibatkan kurang memfokuskan pada hal-hal yang bersifat esensial sehingga akan terkecoh oleh informasi. Maksudnya yaitu akan kurang memahami informasi apa saja yang sebenarnya dibutuhkan untuk dikalkulasi secara tepat, sehingga menghasilkan keputusan keuangan yang tidak didasari pada keyakinan bahwa akan terjadi koreksi secara alamiah 
dari peristiwa yang diinginkan dimasa depan.

Selain itu, akan berefek juga pada kurang mampu untuk membuat pertimbangan dari sudut pandang yang berbeda. Atau dengan kata lain, akan mengalami kekakuan cara berpikir yang dapat mengakibatkan kesulitan untuk merevisi keyakinan yang ada pada benak, sehingga dapat mengarahkan pada cara berpikir yang bias, yakni cara berpikir yang mencoba untuk mengetahui suatu pola yang sebenarnya tidak ada. Tambahan, akan kurang mudah mengembangkan ekspektasi yang realistis, sehingga dapat mengambil tindakan-tindakan efektif untuk mencapai tujuan.

Von, Marklein, dan Rheinbach (2009: 18-20) mempertegas dengan mengungkapkan bahwa gambler fallacy akan berdampak pada konsumsi yang berlebihan. Penjelasannya yaitu akan berdampak pada bagaimana seseorang berkeyakinan bahwa tidak akan terjadi perubahan mendadak pada pandapatan (shock income) dalam jangka pendek sehingga akan terus melakukan pembelian secara tidak normal, walaupun pada kenyataannya belum tentu terjadi. Sebaliknya seseorang yang cenderung berpikir menggunakan gambler fallacy akan memiliki keyakinan bahwa kondisi keuangan yang sedang dalam kondisi menurun hanyalah sementara dan dalam jangka pendek akan meningkat lagi sehingga akan terus-menerus berbelanja secara tidak normal.

Lebih lanjut, bahwa kedua bias sebelumnya dapat di alami seseorang secara bergantian tergantung pada trend pendapatan. Logikanya yaitu dalam kondisi pendapatan yang terus-menerus meningkat ataupun konstan maka seseorang cenderung akan menggunakan hot hand fallacy dan begitu juga sebaliknya jika terjadi perubahan pendapatan yang tidak dinginkan. Lebih dalam lagi bahwa penggunaan kedua cara berpikir diatas dapat menyebabkan seseorang mengakumulasi hutang yang berlebihan. Maksudnya yaitu dengan beranggapan tidak akan terjadi perubahan pendapatan maka seseorang akan terdorong untuk menggunakan utang untuk memenuhi kebutuhan konsumsi yang tinggi, sehingga akan mengakumulasi hutang secara berlebihan (overindebtness) dan berakibat lanjutan pada mengalami kesulitan keuangan.

Sina (2011) menegaskan lagi melalui hasil penelitian bahwa pengeluaran individu atau pun rumah tangga dapat mengalami bias yang terindikasi dari anggapan bahwa mempertahankan pengeluaran saat ini walaupun peluang terjadinya peristiwa tak terduga sama besarnya dengan yang diharapkan, tidak akan berefek pada kemampuan berbelanja di masa mendatang. Implikasinya adalah pola berbelanja tersebut akan diulang terus-menerus dan 
tidak terasa akan menambah biaya yang harus dikeluarkan untuk membiayai kebutuhan.

Selain itu, cara berpikir gambler fallacy juga dapat saja mengalami hot hand fallacy menimbang adanya faktor situasi, maksudnya adalah ketika situasi ekonomi membaik dan pendaptan mengalami peningkatan, akan mendorong individu atau pun rumah tangga bertendensi meyakini bahwa kondisi tersebut akan bertahan, walaupun pada kenyatannya tidaklah demikian karena pada prinsipnya nilai peluang peristiwa yang diharapkan dan yang tidak diharapkan sama besarnya.

Sementara itu, Yoong (2010: 13) menyatakan bahwa kekurangpahaman akan nilai peluang dari suatu proses random akan menyebabkan individu bias dalam mencermati peristiwaperistiwa dimasa depan seperti mengabaikan asuransi serta tabungan pensiun untuk memproteksi dari peristiwaperistiwa yang tidak diharapkan. Selain itu dijelaskan juga bahwa menggunakan cara berpikir gambler fallacy kemungkinan dapat menyebabkan seseorang membuat rencana tabungan pensiun yang bias karena hanya menggunakan informasi yang terbatas pada saat membuat keputusan tentang asetaset apa saja yang sebaiknya dimiliki.

Lebih lanjut, dengan manajemen risiko yang kurang baik disebabkan cara berpikir yang bias maka dapat berakibat lanjutan pada perencanaan keuangan yang kurang tepat. Nalarnya, seseorang cenderung akan mengalami kesalahan dalam mengelola kebutuhan uang untuk pembelian dan berakibat pada mengalami tabungan yang defisit. Selain itu juga dengan anggapan pendapatan masa lalua kan berlanjut dimasa yang akan datang, dapat mengakibatkan seseorang tidak melakukan investasi yang menguntungkan (profitable) untuk mendapatkan atau mungkin mempertahankan arus kas dimasa yang akan datang.

\section{KESIMPULAN}

\section{Mencapai kebebasan}

keuangan merupakan impian banyak orang, hanya saja untuk mencapainya tidak semua orang mampu karena mengalami bias. Tepatnya mengalami gambler fallacy sehingga keliru mengelola keuangan yang terindikasi dari proses pembuatan keputusan keuangan yang menyepelekan nilai peluang. Lebih spesifik lagi yakni mengalami gambler fallacy ketika membuat keputusan keuangan akan mengakibatkan pola pengeluaran dan menabung menjadi keliru dan hal ini dapat menjadi siklus keuangan individu atau pun rumah tangga semakin jauh dari terwujudnya kebebasan keuangan. Untuk itu, cara yang dapat dilakukan untuk mereduksi gambler fallacy ketika membuat keputusan keuangan yakni milikilah keyakinan 
(system believe) bahwa peluang mengalami kenaikan dan penurunan pendapatan sama besarnya serta jangan terlau cepat membuat keputusan keuangan melainkan dipikir terlebih dahulu.

\section{DAFTAR PUSTAKA}

Dohmena, T, Falkb, A, Huffmanc, D, Markleind, F. \& Sundee. 2009. Biased probability judgment: Evidence of incidence and relationship to economic outcomes from a representative sample. Journal of Economic Behavior \& Organization 72 (2009) 903-915

Hirschey, M. \& Nofsinger R. J. 2008. Invesment; Analysis and behavioral. McGrawHill/Irwin. New York-America, 10020

Kahneman, D. \& Frederick, S. 2001. Representativeness Revisited: Attribute Substitution in Intuitive Judgment.P1: GEM/FYX P2: GEM/FYX QC: GEM/UKS T1: GEM CB419Gilovich CB419-02 September 10, 2001 15:58

Karvof, A. 2010. Kaya dengan CEPIL; cara cerdas meraih kekayaan dan keberkatan finansial. Elex media komputindo. Jakarta

Kontan. 2011. Konsumen semakin yakin berbelanja. Edisi tanggal 10 November 2011

Krishna, A, Rofaida, R. \& Sari, M. 2010. Analisis tingkat literasi keuangan di kalangan mahasiswa dan faktor-faktor yang mempengaruhinya (Survey pada Mahasiswa Universitas Pendidikan Indonesia). Proceedings of The 4th International Conference on Teacher Education; Join Conference UPI \& UPSI Bandung, Indonesia, 8-10 November 2010

Policy Studies Institute 2006. Designing policy to influence consumers: Consumer behavior relating to the purchasing of environmentally preferable goods.

ENV.G.1/FRA/2006/0073 $2^{\text {nd }}$

Senduk, S. 2004. Siapa bilang jadi karyawan ngak bisa kaya; lima kiat praktis mengelola gaji agar bisa kaya. Elex media komputindo. Jakarta

Shefrin , H. 2007. Behavioral corporate finance: decision that create value. McGrawHill/Irwin

$\begin{array}{lrr}\text { Sina, } & \text { P. G. } & 2011 . \\ \text { Representataiveness } & \text { Bias } \\ \text { Dan Demografi. } & \text { Tesis } \\ \text { Program S2 } & \text { Magister } \\ \text { Manajmen Universitas } & \text { Kristen } \\ \text { Satya Wacana } & \text { (tidak } \\ \text { dipublikasikan). } & \end{array}$

Sina, P. G. 2011. Literasi Ekonomi. Independent paper 2011

Von, V, Marklein, F. \& Rheinbach. A. 2009. Essays in Behavioral 
Peter Garlans Sina: Perilaku Gambler Fallacy Dalam Mengelola Kevangan Pribadi

Public Economics. InauguralDissertation

Warsono. 2010. Prinsip-prinsip dan

praktik keuangan pribadi. Journal of science. Volume 13 Nomor 2 Juli Desember 2010 